\title{
The Influence of Web-Based Learning and Learning Independence toward Student's Scientific Literacy in Chemistry Course
}

\section{Ucu Cahyana}

State University of Jakarta, Indonesia, u.cahyana@yahoo.com, ucahyana@unj.ac.id

\section{Sri Supatmi}

State University of Jakarta, Indonesia, patmi76@yahoo.co.id

\section{Erdawati}

State University of Jakarta, Indonesia, erda_wati_0912@yahoo.com

\section{Yuli Rahmawati}

State University of Jakarta, Indonesia, yrahmawati@unj.ac.id

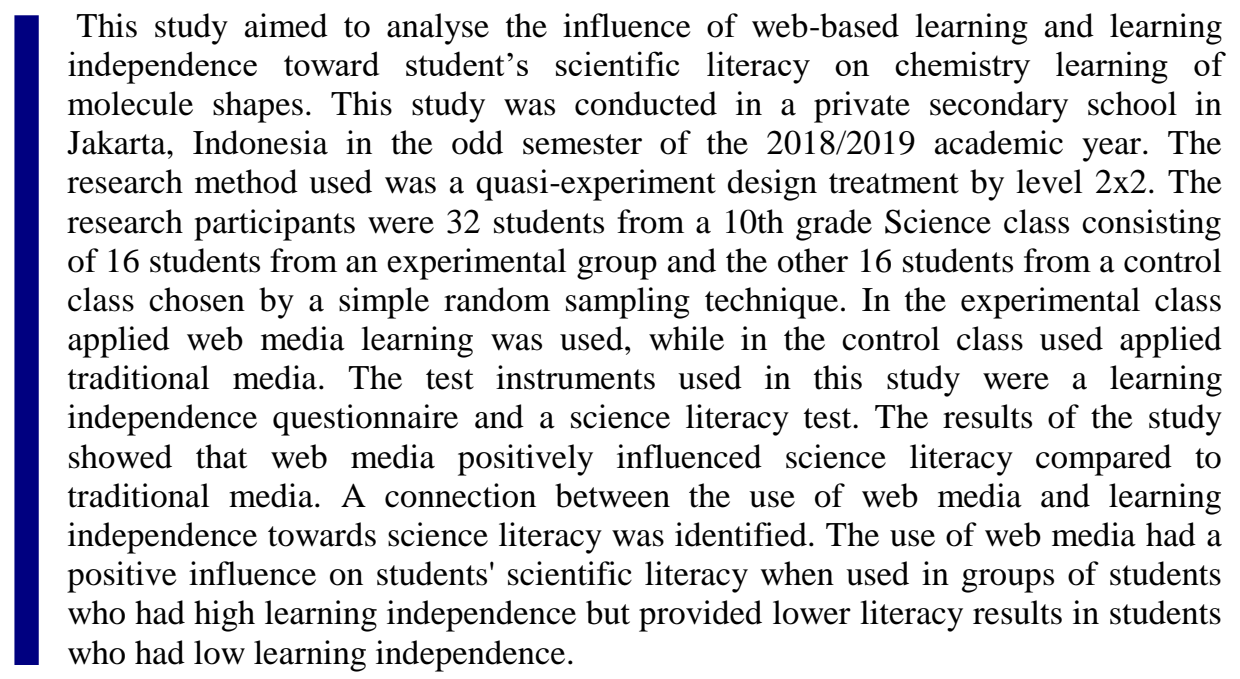

Keywords: web-based learning, science literacy, learning independence, molecule shape, chemistry course

Citation: Cahyana, U., Supatmi, S., Erdawati, \& Rahmawati, Y. (2019). The Influence of Web-Based Learning and Learning Independence toward Student's Scientific Literacy in Chemistry Course. International Journal of Instruction, 12(4), 655-668. https://doi.org/10.29333/iji.2019.12442a 


\section{INTRODUCTION}

Education in the 21st century highlights globalization and Internationalization (Boholano, 2017). Education has an important role in shaping students who have the skills to learn and innovate, especially using technology and information so they can work and earn a living (Shabrina \& Kuswanto, 2018). For this reason, learning in the 21 st century must be able to integrate technology, information and communication in the teaching and learning process (Hargreaves \& Shirley, 2012; Yeop, Yaakob, Wong, Don, $\&$ Zain, 2019). Learning not only uses computers as an offline learning resource but is developed online through web-based learning. The use of the web in learning provides opportunities for students to be able to build their own knowledge and develop critical thinking skills (Kusmawan, 2015). The use of the web in learning can also support the improvement of students' scientific literacy especially in chemistry learning.

Science literacy is the ability to combine scientific ideas and concepts between various disciplines, as well as science practices (Shwartz, Ben-Zvi, \& Hofstein, 2006). According to the National Academy of Science (NAS) scientific literacy is the knowledge, scientific concepts, and scientific processes needed to make decisions and to participate in society, culture and economics (NAS, 2016). Whereas one of the most comprehensive survey programs aimed at assessing scientific literacy is the Program for International Student Assessment (PISA) of the Organization for Economic Cooperation and Development (OECD) defining scientific literacy as the ability to engage in issues related to science and with scientific ideas as reflective citizens (OECD, 2016). Science literacy is also defined as the ability to understand science meaningfully and be able to apply it in daily life (DeBoer, 2000).

The condition of scientific literacy globally is low (Miller, 2007), as is the case in Indonesia. The 2015 PISA results put Indonesia at $64^{\text {th }}$ out of 72 countries with an average value of 403 for scientific literacy, well below the international average score of 500 (Balitbang, 2016). Analysis of the 2015 PISA results show that $1.2 \%$ of Indonesian students are below level $1 \mathrm{~b} ; 14.4 \%$ are at level $1 \mathrm{~b} ; 40.4 \%$ are at level $1 \mathrm{a} ; 31.7 \%$ are at level 2 and only $10.6 \%$ of students are at level $3 ; 1.6 \%$ of students are at level $4 ; 0.1 \%$ of students are at level 5 and no Indonesian students have reached level 6 . These conditions indicate that Indonesian students can only use scientific knowledge in some familiar life circumstances that require low cognitive levels and they have not been able to use scientific knowledge in various complex life circumstances that require high cognitive levels (OECD, 2016).

Chemistry is one of science subjects that focusing on materials, its changes and energy (Brady, 2009). The characteristics of chemistry learning are associated with three levels of macroscopic, microscopic and symbolic (Johnstone, 1991). There for science literacy is very closely related to chemistry. These characteristics challenges students in understanding chemistry concepts. According to Rahmawati and Ridwan (2017), it is expected in Indonesia, students are not only understanding the chemistry concepts, but also applying it their lives. Generally, students faced difficulties in visualizing the submicroscopic level and relating it with chemical representative levels (Chittleborough \& Treagust, 2007). 
One effort to overcome this difficulty is to integrate technology in science learning. Science and technology are inseparable parts where technology plays a role in forming learning to be more attractive and motivating to students (DeBoer, 2000). One of the uses of technology in learning is the use of web learning. The use of the web utilizes internet technology that can present virtual classes that can make learning more effective and improve the learning process (Poon, Low, \& Yong, 2004; Tamrakar \& Mehta, 2011). Web-based learning allows students to access material anytime and anywhere, thereby increasing interaction between students, students with subject matter, and students with teachers and it supports increased learning outcomes (Usta, 2011). Webbased learning also helps students understand abstract material through visual support (Sedig \& Liang, 2006). Web-based learning also facilitates students in remembering, understanding, applying, analyzing, and evaluating subject matter so as to improve learning outcomes (Kay, 2011). This can improve critical thinking skills and problem solving (Moayeri, 2014).

The use of the web is expected to be able to overcome the difficulties of students in understanding the material in molecule shapes and the attraction between molecules which is actually an abstract material (Uyulgan \& Akkuzu, 2016). Mastery of this material requires understanding at the microscopic (particulate structure), macroscopic (physical structure), and symbolic level (chemical notation and mathematical symbols), usually students experience difficulty in combining these three levels of representation (Uyulgan, Akkuzu, \& Alpat, 2014; Wang, 2007). The use of animated media in molecular shape material on the web will help students learn material molecules independently (Usta, 2011).

The use of web learning will be more effective if it is supported by learning that involves students actively so that students can develop the ability to think critically (Rubini, Ardianto, Puspitasari, \& Permana, 2017; Babalola, 2013). In this case the use of web learning is integrated with the problem-based learning model supporting the formation of the learning environment. Problem-based learning (PBL) is learning that involves students actively in the problem-solving process both individually and in groups while the teacher acts as a facilitator (Newman, 2005). The use of PBL in this learning process will be able to help student's develop critical thinking skills (Tayyeb, 2013; Sendag \& Odabasi, 2009), gain knowledge, collaborate in groups, and improve independence and problem-solving skills (Tosun \& Taskesenligil, 2013; Newman, 2005).

Learning using web media integrated with problem-based learning models requires students to actively seek information themselves (Tarhan \& Sesen, 2013; Newman, 2005). So that students are motivated to be responsible for their own learning. Students are also required to have the ability to work with others to increase the depth and breadth of their own learning. For this reason, the use of the web in learning requires student learning independence.

Learning independence is needed when learning because students who have learning independence can build ideas and knowledge so they can improve their own competencies and improve learning outcomes (Kulsum, Kustono, \& Purnomo, 2017). 
Students will also actively learn (not passively), receive knowledge (Boekaerts, 1997) and will be able to manage their learning, their time, and themselves (Field, Duffy, \& Huggins, 2015).

Based on the description above, the researchers conducted research on the effect of webbased learning and independence on scientific literacy.

\section{METHOD}

This research was conducted at a secondary school in Jakarta, Indonesia in the odd semester of the 2018/2019 academic year. A quasi-experimental research method design treatment by level $2 \times 2$ was used. The research design can be seen in table 1 below.

Table 1

Research Design

\begin{tabular}{lll}
\hline Learning independence & Learning media & \\
\cline { 2 - 3 } & Web media $\left(\mathrm{A}_{1}\right)$ & Traditional media $\left(\mathrm{A}_{2}\right)$ \\
\hline High learning independence $\left(\mathrm{B}_{1}\right)$ & $\mathrm{A}_{1} \mathrm{~B}_{1}$ & $\mathrm{~A}_{2} \mathrm{~B}_{1}$ \\
\hline Low learning independence $\left(\mathrm{B}_{2}\right)$ & $\mathrm{A}_{1} \mathrm{~B}_{2}$ & $\mathrm{~A}_{2} \mathrm{~B}_{2}$ \\
\hline
\end{tabular}

The participants in this study were 32 students that are in the science major consisting of 16 students who had high learning independence ( 8 students in the experimental group and 8 students in the control group) and 16 students who had low learning independence ( 8 students from the experimental group and 8 students from the control group) selected by a simple random sampling technique. The experimental group learned with web media and the control group learned through traditional media. The learning process was carried out by applying a problem-based learning model in both the experimental group and the control group.

Data collection was carried out using tests and questionnaires, namely a scientific literacy test and a learning independence questionnaire. Questionnaires used to measure learning independence were adapted from self-directed learning (Williamson, 2007) and adjusted to chemistry learning in the form of 49 attitude statements developed on a 1-5 Likert scale. Content validity was tested by expert lecturers and validity items with product moment correlation analysis techniques and reliability were tested using Cronbach Alpha formula obtained $r_{\text {value }}=0.930$. The learning independence questionnaire was given to 30 students in the experimental group and 30 students in the control group before the study, then in each class the highest of $27 \%$ were taken as a group of students who had high learning independence and the lowest $27 \%$ as a group of students who had low learning independence.

The measurement of scientific literacy in molecular shape material used a scientific literacy test instrument developed with reference to the PISA 2015 which included three aspects; context, knowledge, and competency, in the form of 15 description questions. Content was tested by lecturers and item validity with product correlation techniques moment was carried out and a reliability test with Cronbach Alpha formula obtained $\mathrm{r}=$ 0.948 . This test is given to 32 students in the experimental class and the control class who have high and low learning independence. 
Prior to analysis, a prerequisite test was carried out, namely a normality test using the Lilliefors test and a homogeneity test using the Fisher test followed by the Bartlett test. Four hypotheses were tested in this study, main effect, interaction effect (which was analyzed by two-way analysis) followed by the Tukey test to test the third hypothesis and the fourth hypothesis (simple effect).

\section{FINDINGS AND DISCUSSION}

Once the results of the research data fulfilled the analysis prerequisite test, the hypothesis was tested, and the following data was obtained.

Table 2

Results of Two-Way ANOVA Calculations

\begin{tabular}{llllll}
\hline Source of variant & $\mathrm{JK}$ & $\mathrm{db}$ & $\mathrm{RJK}$ & $\mathrm{F}_{\text {count }}$ & $\mathrm{F}_{\text {table }}$ \\
\hline Learning media $(\mathrm{A})$ & 225,781 & 1 & 225,781 & 10,590 & 4,200 \\
\hline Independence $(\mathrm{B})$ & 101,531 & 1 & 101,531 & 4,755 & 4,200 \\
\hline Interaction $(\mathrm{AxB})$ & 1391,581 & 1 & 1391,581 & 65,240 & 4,200 \\
\hline In group & 579,11 & 28 & 21,330 & & \\
\hline Total & 195603,000 & 32 & & & \\
\hline
\end{tabular}

Next the researcher conducted Tukey test and got results below.

Table 3

The Result of Calculating the Tukey Test

\begin{tabular}{llll}
\hline Group & $n$ & $\mathrm{Q}_{\text {count }}$ & $\mathrm{Q}_{\text {table }}$ \\
\hline $\mathrm{A}_{1} \mathrm{~B}_{1}$ & 8 & 11,530 & 4,530 \\
$\mathrm{~A}_{1} \mathrm{~B}_{2}$ & 8 & 4,830 & 4,530 \\
\hline $\mathrm{A}_{2} \mathrm{~B}_{1}$ & 8 & 4,5 & \\
$\mathrm{~A}_{2} \mathrm{~B}_{2}$ & 8 & & \\
\hline
\end{tabular}

The results of the two-way ANOVA test and the Tukey test in Tables 2 and 3 can be elaborated on the following four hypotheses.

\section{Effect of the use of chemistry learning web media on scientific literacy}

The results of hypothesis testing with two-way ANOVA (table 2) obtained $\mathrm{F}_{\text {count }}=10.59$ with $F_{\text {table }}$ value $=4.20$. Because $F_{\text {count }}>F_{\text {table }} H_{0}$ is then rejected. From this, it can be concluded that there is a difference in scientific literacy between students who use web media and students who use traditional media.

In the experimental group using web media, the average value of science literacy was 80.3 with a standard deviation of 9.81 while in the control group using traditional media the average value of scientific literacy was 75.07 with a standard deviation of 6.57 . This shows that the use of web media has a positive influence on scientific literacy compared to traditional media.

The using of web media can improve scientific literacy related to we characteristic that support learning to be more effective and quality (Yildirim \& Sensoy, 2018). 
Web learning is web media that contains teaching materials that are prepared, implemented, and utilized online. The web help students understand molecular shape material because the molecular shape on the web is presented in three-dimensional animated models that present molecular shapes correctly. In addition, material on the web takes the form of text, images and videos that make learning interesting (Sharma \& Sharma, 2017; Cabada et al, 2018) and help students find their own answers to the problems given (Ziden, 2013), encouraging them to build their own knowledge (Sharma \& Sharma, 2017. Web media is also fun to use so it can increase motivation (KOC, 2005; Samir, Islam, \& Naglaa, 2014) and motivate students to their own learning (Lin, Chen, \& Liu , 2017) The features available on the web also make it easier for students to find information quickly Evaluation, practice questions and molecular shape simulations on the web also help students measure their level of understanding of molecular forms of material that will increase self-confidence (Samir, Islam, \& Naglaa, 2014; Lin, Chen, \& Liu, 2017). Likewise the material presented on the web running on the internet also made it possible for students to access material in school and outside of school (Cook, 2007; Saini, Wahid, \& Purohit, 2014) via mobile phones or laptops, this certainly makes it easier for students to manage learning at their own pace (Zimmerman BJ, 1989) although this must be supported by the availability of adequate internet.

In this study power point was used as a learning media in the control group. This media has limitations as it cannot be accessed online resulting in limited usage. In the power point media learning environment, it also does not support the formation of meaningful learning because it does not stimulate students in audio and visual terms (Penciner, 2013). Power point does not support active learning because, in the learning process that uses media, the teacher usually explains and students listen and take notes. The role of students in this learning is as a passive learner (Saini, Wahid, \& Purohit, 2014). This can cause students to become bored and sleepy because students are not actively involved (Boumová, 2008). This results in the use of power point as a learning medium that is less successful in improving learning and can even make students less interested in learning (Xingeng \& Jianxiang, 2012).

Overall, it can be said that the use of web media in the learning process will make learning more effective and can improve students' scientific literacy in molecular form material compared to traditional media (Saini, Wahid, \& Purohit, 2014; Atan, Sulaiman, \& Idrus, 2005; Lin, Chen \& Liu, 2017).

Interaction of the use of web media (A) and student learning independence (B) on student scientific literacy.

Based on the results of hypothesis testing with two-way ANOVA (table 2) obtained $\mathrm{F}_{\text {count }}$ of 65.240 with $\mathrm{F}_{\text {table }}$ at the $5 \%$ significance level of 4.200 . Because $F_{\text {count }}>F_{\text {table }}$ then $\mathrm{H}_{0}$ is rejected so it can be concluded that there is an interaction of the use of learning media and learning independence on students' scientific literacy. The learning media used were web media and traditional media.

The interaction between the use of learning media and learning independence on students' scientific literacy is shown in the following graph. 


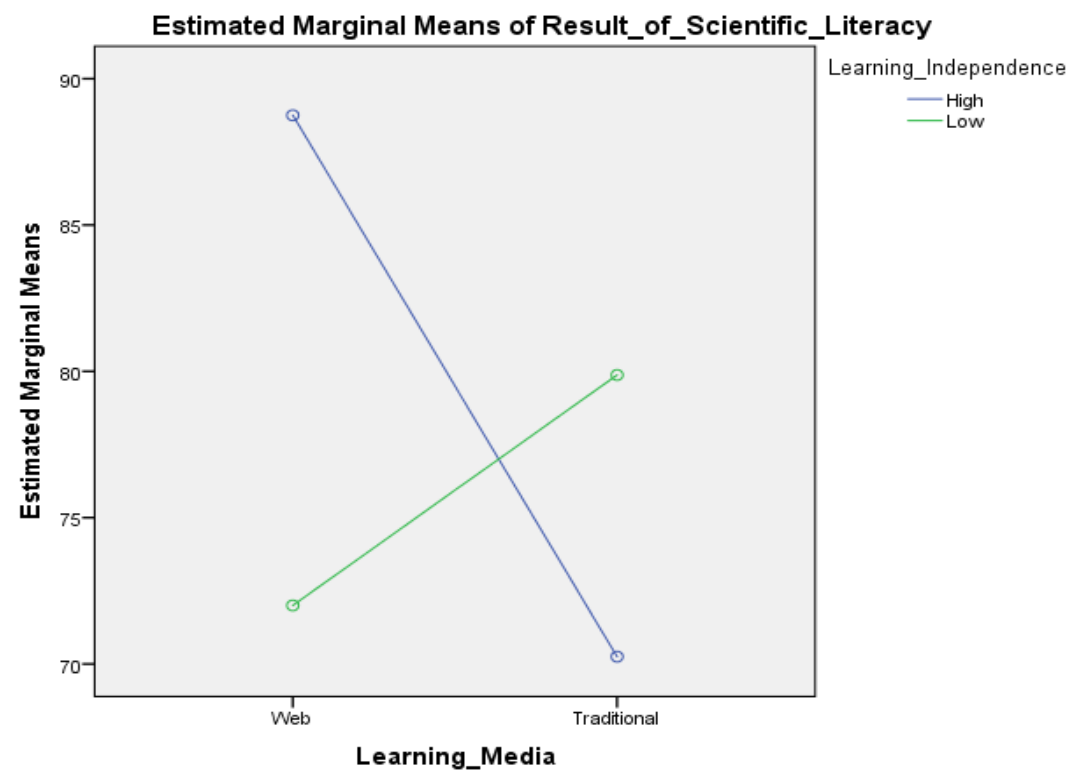

Figure 1

Effect of Interaction between Learning Media and Learning Independence.

The interaction shows that the use of web media and traditional media has a different influence on students' scientific literacy if applied to groups of students who have different independence. Figure 1 also shows that web media is more effectively used in groups of students who have high learning independence whilst traditional media is more effectively used in groups of students who have low learning independence

The use of the web in learning makes the learning process interesting and not boring because it involves students actively. By giving problems first, students are required to seek information and students will try to solve the problems given. When problems are given by students, they will also be challenged to solve them, this will certainly develop students' thinking skills and problem-solving skills (Tayyeb, 2013).

The use of the web requires learning independence because students are required to explore and digest information from the web independently. The use of the web requires responsibility, understanding one's own learning, motivation for learning and collaboration with the teacher compiling the learning environment (Nalatambi, Shahudin, \& Zaludin, 2015) so students would want to find information from the web and not be affected to open other sites on the internet that will affect the learning process and get optimal results. In the learning process students who have high independence do not just rely on books or teacher explanations as the main learning source but they are also actively involved in the learning process (Cahyana, Paristiowati, Savitri, \& Hasyrin, 2017). These conditions enable students to build their own 
knowledge (Ziden, 2013) so that effective and quality learning can be developed critical thinking skills and problem-solving abilities so that they can improve scientific literacy (Rusilowati et al, 2016; Saini, Wahid, \& Purohit, 2014).

While learning that uses traditional media does not require students to be actively involved in learning. Students tend to listen and record lessons and their teachers become the main source of knowledge for them (Penciner, 2013; Scrivener, 2005). For this reason, traditional media is more suitable for students who have low learning independence

Based on the description above, it can be concluded that there is an interaction of web media and learning independence towards scientific literacy.

\section{Differences in scientific literacy between groups $A_{1} B_{1}$ and $A_{2} B_{1}$.}

From the results of testing the hypothesis with the Tukey test (table 3), the $\mathrm{Q}_{\text {count }}$ is 11.53 with $\mathrm{Q}_{\text {table }}$ at the $5 \%$ significance level of 4.53 . Because $\mathrm{Q}_{\text {count }}>\mathrm{Q}_{\text {table }}$ then $\mathrm{H}_{0}$ is rejected so it can be concluded that there are differences in scientific literacy between students using web media and students who use traditional media in groups of students who have high learning independence.

In the experimental group that used web media the average scientific literacy score in the group of students who had high learning independence wass 88.75 with a standard deviation of 5.47 while in the control group which used traditional media the average scientific literacy in the group of students who had high learning independence amounted to 70.25 with a standard deviation of 4.23 . This shows that the scientific literacy of students who used web media was higher than students who used traditional media in groups of students who had high learning independence. Web media is more effective than traditional media for students who have high learning independence. These results are related to the characteristics of web media which requires learning independence to use.

Web media contains content in the form of text, images, animation, and videos (Poon, Low, \& Yong, 2004), which will motivate students visually and encourage students to find information independently and build their own knowledge (Sharma \& Sharma, 2017; Ziden, 2013; Wei et al, 2017). The use of the web that utilizes internet service requires the willingness and motivation of students to access information both at school and outside of school (Cook, 2007; Saini, Wahid, \& Purohit, 2014) via mobile phones or laptops so students can learn at their own pace. The use of the web also requires students to be actively involved in finding information, to find solutions to problems given (Samir, Islam, \& Naglaa, 2014; Meyer, Haywood, Darshan, \& Faraday, 2008).

The web characteristics allow students to manage their own learning so students can be responsible for their own learning (Field, Duffy, \& Huggins, 2015). This resulted in learning using the web more effectively and beneficial for students who have high independence (Saini, Wahid, \& Purohit, 2014). 


\section{Differences in scientific literacy between groups $A_{1} B_{2}$ and $A_{2} B_{2}$}

From the results of testing the hypothesis with the Tukey test (table 3), the $\mathrm{Q}_{\text {count }}$ is 4.83 with $\mathrm{Q}_{\text {table }}$ at the $5 \%$ significance level of 4.53. Because $\mathrm{Q}_{\text {count }}>\mathrm{Q}_{\text {table }}$ then $\mathrm{H}_{0}$ is rejected so it can be concluded that there are differences in scientific literacy between students who use web media and students who use traditional media in groups of students who have low learning independence.

In the experimental class that used web media the average score for scientific literacy in the group of students who had low learning independence was 72.00 with a standard deviation of 4.00, while in the control group using traditional media the average scientific literacy score for the group of students who had low learning independence was 79.88 with a standard deviation of 4.69. This shows that the scientific literacy of students using traditional media was higher than students who use web media in groups of students who have low learning independence. Traditional media is more effective for students who have low learning independence compared to web media. These results relate to the characteristics of traditional media which does not require students to be actively involved in the learning process.

The traditional media used in this study is power point. Power point is media that is often used in presentations. Power points are usually used by teachers in delivering subject matter with lectures while students record and listen without being actively involved in learning (Penciner, 2013). In the process of learning communication also occurs in one direction, it tends to make students passive students (Boumová, 2008; Saini, Wahid, \& Purohit, 2014; Scrivener, 2005) and place teachers as a source of knowledge (Scrivener, 2005). For this reason, the success of learning with this media is very dependent on the skills of the teacher in writing and speaking effectively (Saini, Wahid, \& Purohit, 2014).

Based on the characteristics of traditional media, this media is more effective to be used for students who have low learning independence, because students who have low learning independence tend to be passive in learning and accept lessons as it is (Cahyana, Paristiowati, Savitri, \& Hasyrin, 2017). They tend to listen, record the subject matter without being actively involved. Students with characteristics such as this usually prefer traditional learning where the teacher explains in front of the class then at the end of the lesson students are given a problem exercise. In the learning process the teacher will guide and deliver material at length so that in traditional classes students who have low learning independence will be more successful (Williamson, 2007).

\section{CONCLUSION}

Web media has a positive effect on scientific literacy compared to traditional media. The use of web media encourages students to build their own knowledge so as to improve problem solving and critical thinking skills.

There is a interaction between the use of web media and learning independence in developing scientific literacy which shows that the use of web media has a different influence on groups of students with varying degrees of learner independence. The use 
of web media requires motivation and a willingness to search for information independently while the use of traditional media situates students as passive learners where they tend to take notes and listen so that communication occurs only in one direction.

The use of web media in the learning process must pay attention to the indicators of student learning independence. Based on the results obtained, the use of web media will have a positive effect on students' scientific literacy, when applied to groups of students who have high learning independence. Conversely, in groups of students with low learning independence science literacy students taught using web media are lower than those taught using traditional media.

\section{REFERENCES}

Atan, H., Sulaiman, F., \& Idrus, R. (2005). The effectiveness of problem-based learning in the web-based environment for the delivery of an undergraduate physics course. International Education Journal, 6(4), 430-437.

Babalola, J. (2013). Scientific literacy: Conceptual overview, importance and strategies for improvement. Journal of Educational and Social Research, 3(1), 265-273. doi: 10.5901/jesr.2013.v3n1p265.

Balitbang. (2016). Tentang PISA (Program for Internasional Student Assesment); https://www.kemdikbud.go.id/main/blog/2016/12/peringkat-dan-capaian-pisaindonesia-mengalami-peningkatan. Jakarta: Kementerian Pendidikan dan Kebudayaan.

Boekaerts, M. (1997). Self-regulated learning: A new concept embraced by researchers, policy makers, educators, teachers and students. Learning and Instruction, 7(2), 161186. doi: 10.1016/S0959-4752(96)00015-1.

Boholano, H. (2017). Smart social networking: 21st century teaching. Research in Pedagogy, 7(1), 21 - 29. doi: 10.17810/2015.45.

Boumová, V. (2008). Traditional vs. modern teaching methods: Advantages and disadvantages of each. Ceko: Masaryk University Faculty of Arts .

Brady, J. E. (2009). Chemistry: Matter and its changes. Hokoben: John Wiley \& Sons.

Cabada, R., Estrada, M. L., Hernández, F., Bustillos, R., \& G. C. (2018). An affective and Web 3.0-based learning environment for a programming language. Telematics and Informatics 35(3), 611-628. doi: 10.1016/j.tele.2017.03.005.

Cahyana, U., Paristiowati, M., Savitri, D. A., \& Hasyrin, S. N. (2017). Developing and application of mobile game based learning (M-GBL) for high school students performance in chemistry . EURASIA Journal of Mathematics Science and Technology Education, 13(10), 7037-7047. doi: 10.12973/ejmste/78728.

Chittleborough, G., \& Treagust, D. F. (2007). The modelling ability of non-major chemistry student's and their understanding of the sub-microscopic level. Chemistry Education Research and Practice, 8, 274-292. doi: 10.1039/B6RP90035F. 
Cook, D. A. (2007). Web-based learning: Pros, cons and controversies. Medical Education, 7, 37-41.

DeBoer, G. E. (2000). Scientific literacy: another look at its historical and contemporary meanings and its relationship to science education reform. Journal of Research in Science Teaching, 37(6), 582-601. doi: 10.1002/1098-2736(200008)37:6<582::AIDTEA5>3.0.CO;2-L.

Field, R., Duffy, J., \& Huggins, A. (2015). Teaching independent learning skills in the first year: A positive psychology strategy for promoting law student well-being.$J$ ournal of Learning Design, 8(2), 1-10. doi: 10.5204/jld.v8i2.238.

Hargreaves, A., \& Shirley, D. (2012). The global fourth way: The quest for educational excellence. Corwin, CA: Thousand Oaks.

Johnstone, A. H. (1991 ). Why science is difficult to learn: Things are seldom what they seem. Journal Computer Assisted Learning, 7, 74-83. doi: 10.1111/j.13652729.1991.tb00230.x.

Kay, R. H. (2011). Examining the effectiveness of web-based learning tools in middle and secondary school science classrooms. Interdisciplinary Journal of E-Learning and Learning Objects, 7, 359-374. doi: 10.28945/1534.

Kulsum, U., Kustono, D., \& Purnomo. (2017). Improvement of learning independence and learning outcomes on textile course through hybrid learning model. IOSR Journal Of Humanities and Social Science (IOSR-JHSS), 22(8), 1-5. doi: 10.9790/08372208030105.

Kusmawan, K. (2015). Approach to heightening 21st century learning skills in distance education. In International Conference of Education (ICE) (pp. 7-16). Bandung: AAPG SEG.

Koc, M. (2005). Individual learner differences in web-based learning environments from cognitive, affective and social-cultural perspectives. Turkish Online Journal of Distance Education, 6(4) 12-19.

Lin, M. H., Chen, H. C., \& Liu, K. S. (2017). A study of the effects of digital learning on learning motivation and learning outcome. EURASIA Journal of Mathematics Science and Technology Education, 13(7), 3553-3564. doi: 10.12973/eurasia.2017.00744a.

Moayeri, M. (2014). The impact of web-based learning with a problem-solving approach on logical thinking development. Mathematics Education Trends and Research, 2014, 1-10. doi:10.5899/2014/metr-00055.

Meyer, B., Haywood, N., Darshan, S., \& Faraday, S. (2008). What is independent learning and what are the benefits for students? . London: Department for Children, Schools and Families Research Report 051. 
Miller, J. D. (2007). The impact of college science courses for non-science majors on adult science literacy. A paper presented to a symposium titled "the Critical Role of College Science Courses of Non-Majors"at the annual meeting of the AAS", 18 Feb 2007. San Fransisco.

Nalatambi, S., Shahudin, F., \& Zaludin, Z. (2015). Studens" perception on independent learning and possible impact on the students' performance at pre-university. In Proceedings of ISER 10th International Conference, Kuala Lumpur, Malaysia (pp. 24 28). Kuala Lumpur: ISER.

NAS. (2016). Science Literacy: Concepts, Contexts, and Consequences. Washington, D.C.: National Academies Press.

Newman, M. (2005). Problem based learning: An introduction and overview of the key features of the approach. Journal of Veterinary Medical Education, 32(1), 12-20. doi: 10.3138/jvme.32.1.12.

OECD. (2016). PISA 2015 assesment and analytical framework: Science reading, mathematic and financial literacy. Paris: OECD Publishing.

Penciner, R. (2013). Does PowerPoint enhance learning? Canadian Journal of Emergency Medicine 15(2), 109-112. doi: 10.2310/8000.2013.130756.

Poon, W., Low, K. L., \& Yong, D. G. (2004). A study of web-based learning (WBL) environment in Malaysia. The International Journal of Educational Management, 18(6), 374-385. doi: 10.1108/09513540410554031.

Rahmawati, Y., \& Ridwan, A. (2017). Empowering students' chemistry learning: The integration of nanochemistry in culturally responsive teaching chemistry. Bulgarian Journal of Science Education, 26(6), 813-830.

Rubini, B., Ardianto, D., Puspitasari, I. D., \& Permana, I. (2017). Professional development model for science teachers and based on scientific literacy. In IOP Conference Series: Materials Science and Engineering 166 (pp. 1 - 7). IOP Publishing.

Rusilowati, A., Kurniawati, L., Sunyoto, E., Nugroho, \& Widiyatmoko, A. (2016). Developing an instrument of scientific literacy assessment on the cycle theme. International Journal Of Enviromental \& Science Education, 11(12), 5719 - 5727.

Shabrina, \& Kuswanto, H. (2018). Android-assisted mobile physics learning through Indonesian batik culture: Improving students' creative thinking and problem solving. International Journal of Instruction, 11(4), 287-302. doi: 10.12973/iji.2018.11419a.

Saini, K., Wahid, A., \& Purohit. (2014). Traditional learning versus web based learning: Performance analysis. (IJCSIT) International Journal of Computer Science and Information Technologies, 5(4), 5182-5184.

Samir, M., Islam, A., \& Naglaa, S. (2014). E-learning and students' motivation: A research study on the effect of e-learning on higher education. International Journal of Emerging Technologies inLearning, 9(4), 20-26. doi: 10.3991/ijet.v9i4.3465. 
Shwartz, Y., Ben-Zvi, R., \& Hofstein, A. (2006). The use of scientific literacy taxonomy for assessing the development of chemical literacy among high-school students. Chemistry Education Research and Practice, 7(4), 203-225. doi: 10.1039/B6RP90011A.

Scrivener, J. (2005). Learning teaching. Oxford: Macmillan.

Sharma, R. M., \& Sharma, A. (2017). Using ICT in secondary school science teachingWhat students and teacher in Trinidad and Tobago say? European Journal of Education Studies, 2(3), 197-210. doi: 10.5281/zenodo.251163.

Sedig, K., \& Liang, H. (2006). Interactivity of visual mathematical representations: Factors affecting learning and cognitive processes. Journal of Interactive Learning Research, 17(2), 179-212.

Sendag, S., \& Odabasi, H. F. (2009). Effects of an online problem based learning course on content knowledge acquisition and critical thinking skill. Computers \& Education, 53(1), 132-141. doi: 10.1016/j.compedu.2009.01.008.

Tamrakar, A., \& Mehta, K. (2011). Analysis of effectiveness of web based e-learning through information technology. International Journal of Soft Computing and Engineering (IJSCE), 1(3), 55-59.

Tarhan, L., \& Sesen, B. A. (2013). Problem based learning in acid and based: Learning achievements and students beliefs. Journal of Baltic Science Education, 12, 565-578.

Tayyeb, R. (2013). Effectiveness of problem based learning as an instructional tool for acquisition of content knowledge and promotion of critical thinking among medical students. Journal of the College of Physicians and Surgeon Pakistan, 23, 42-46.

Tosun, C., \& Taskesenligil, Y. (2013). The effect of problem based learning on undergraduate students' learning about solutions and their physical properties and scientific processing skills. Chemistry Education Research and Practice, 14, 36-50. doi: 10.1039/C2RP20060K.

Usta, E. (2011). The effect of web-based learning environments on attitudes of students regarding computer and internet. Procedia - Social and Behavioral Sciences, 28, $262-$ 269. doi: 10.1016/j.sbspro.2011.11.051.

Uyulgan, M. A., \& Akkuzu, N. (2016). An insight towards conceptual understanding: Looking into the molecular structures of compounds. Acta Didactica Napocensia, 9(4), 49-69.

Uyulgan, M. A., Akkuzu, N., \& Alpat, S. (2014). Assessing the students' understanding related to molecular geometry using a two-tier diagnostics. Journal of Baltic Science Education, 1(6), 839-855.

Wang, C. (2007). The role of mental-modeling ability, content knowledge, and mental models in general chemistry students understanding about molecular polarity. Columbia: University of Missouri. 
Wei, Y., \& al, e. (2017). Blended learning versus traditional learning: a study on students' learning achievements and academic press. Paper presented at the 2017 International Symposium on Educational Technology (ISET). Hong Kong, China.

Williamson. (2007). Development of self-rating scale of self directed learning. Nurses Research, 14(2), 66-83. doi: 10.7748/nr2007.01.14.2.66.c6022.

Xingeng, D., \& Jianxiang, L. (2012). Advantages and disadvantages of PowerPoint in lectures to science students. I.J. Education and Management Engineering, 9, 61-65.

Yeop, M. A., Yaakob, M. F., Wong, K. T., Don, Y., \& Zain, F. M. (2019). Implementation of ICT policy (blended learning approach): Investigating factors of behavioural intention and use behaviour. International Journal of Instruction, 12(1), 767-782. doi: 10.29333/iji.2019.12149a.

Yildirim, H. I., \& Sensoy, O. (2018). The effect of science teaching enriched with technological applications on the science achievements of 7 th grade students. Journal of Education and Training Studies 6(9), 53-68. doi: 10.11114/jets.v6i9.3363.

Ziden, A., \& Rahman, R. M. A. (2013). The effectiveness of web-based multimedia application simulation in teaching and learning. International Journal of Instruction, $6(2), 211-222$.

Zimmerman, B. (1989). A social cognitive view of self-regulated academic learning. Journal of Educational Psychology, 81(3), 329-339. doi: 10.1037/0022-0663.81.3.329. 